\title{
Phytochemical analysis and antioxidant and anticancer activities of mastic gum resin from Pistacia atlantica subspecies kurdica
}

This article was published in the following Dove Press journal:

OncoTargets and Therapy

\author{
Heshu Sulaiman Rahman ${ }^{1-3}$ \\ 'Department of Clinic and Internal \\ Medicine, College of Veterinary \\ Medicine, University of Sulaimani, \\ Sulaimani, Kurdistan Region, Republic \\ of Iraq; ${ }^{2}$ Department of Medical \\ Laboratory Sciences, College \\ of Science, Komar University of \\ Science and Technology, Chaq- \\ Chaq Qularaisee, Sarchinar District, \\ Sulaimani, Kurdistan Region, \\ Republic of Iraq; ${ }^{3}$ Department of \\ Cell and Molecular Biology, Faculty \\ of Biotechnology and Biomolecular \\ Sciences, University Putra Malaysia, \\ Serdang, Selangor, Malaysia
}

Background: The mastic gum resin has been used in traditional Kurdish medicine for treating various disorders such as topical wound and gastric ulcer. The study designed to evaluate the total polyphenol and flavonoid content, free radical scavenging activity, and anticancer effects of mastic gum resin derived from Pistacia atlantica subspecies kurdica.

Materials and methods: Folin-Ciocalteau and the aluminum chloride colorimetric assays were used to determine the total phenol and flavonoid contents in the mastic gum resin respectively. Whereas, DPPH and ABTS+ assays were used to determine the antioxidant activities of mastic gum resin. Regarding anticancer activities, the MTT assay was used to study the effect of mastic gum resin on the proliferation of various cancer cells and the morphological changes were identified after Acridine Orange/Propidium Iodide staining. Flow cytometry was applied to determine the influence of mastic gum resin on the apoptosis rate by Annexin V double staining and to investigate the influence on cell cycle progression. Caspase colorimetric assay was used to estimate the hallmark enzyme of apoptosis, and finally RNA were obtained from COLO205 cells and analyzed by qRT-PCR analyses.

Results: The MTT results showed that the mastic gum resin at concentrations from 0.01 to $100 \mu \mathrm{M}$ induced death of cancer cells in a dose and time-dependent manner. The mastic gum resin suppressed proliferation of human cancer cells with $72 \mathrm{~h} \mathrm{IC}_{50}$ value of $15.34 \pm 0.21$, $11.52 \pm 0.18,8.11 \pm 0.23$ and $5.2 \pm 0.8 \mu \mathrm{g} / \mathrm{mL}$ for bile duct cancer (cholangiocarcinoma) (KMBC), pancreatic carcinoma (PANC-1), gastric adenocarcinoma (CRL-1739), and colonic adenocarcinoma (COLO205) cells, respectively. Normal human colon fibroblast (CCD-18Co) cells were not adversely affected by resin treatment. Flow cytometry showed that the mastic gum resin significantly $(P<0.05)$ arrested COLO205 cell proliferation at the $\mathrm{G} 2 / \mathrm{M}$ phase of cell cycle. The resin caused apoptotic morphological changes in COLO205 cells. The apoptotic effect to mastic gum resin was via the mitochondrial as shown by the up-regulation of Bax, down-regulation of Bcl-2 genes, and activation of caspase- 9 and -3 activities.

Conclusion: It was confirmed that the antiproliferative efficacy of the resin is positively correlated with its polyphenolic contents, suggesting a causal link related to exudate content of phenolic acid and flavonoids. The results revealed that the mastic gum resin has potential to be developed as an anticancer and antioxidant product due to its high content of polyphenol compounds.

Keywords: natural plant exudate, polyphenolic contents, free radical scavenging, apoptosis

\section{Introduction}

Most recent data have shown that the number of cancer patients and mortality due to cancers are on the rise. Despite great advances in the development of new and innovative therapeutic strategies, cancer remains one of the leading causes of death. ${ }^{1}$ Although new cancer therapeutic and carcinostatic agents have been developed, their effects on cancer patients are generally not obvious. 
In recent years, natural herbal metabolites have gained interest as compounds for alternative remedies for various diseases. ${ }^{2}$ According to the World Health Organization (WHO), almost $65 \%$ of the world's population has included plants and traditional medicine as the additional modality in health care. ${ }^{3}$ In fact, several chemical compounds isolated from plants and traditional medicine have been shown to kill rapidly dividing cells, ${ }^{4}$ thus revealing their great potential to be developed as anticancer agents. However, the use of these compounds is limited by their narrow beneficial index, considerable toxicity, and delivery issues during treatment. $^{5}$

The genus Pistacia belongs to a cosmopolitan family Anacardiaceae that comprises approximately 70 genera and more than 600 species. $^{6}$ The species of the genus Pistacia are evergreen, aromatic, nutraceutical, and deciduous resinbearing shrubs and fast-growing xerophytic trees that can reach heights of 8-10 m. ${ }^{7}$ Pistacia plant parts including leaf, fruit, stem, exudate, and essential volatile oil have been chemically characterized and used to treat various human ailments ${ }^{8,9}$ because of their antiatherogenic, ${ }^{10}$ hypoglycemic, ${ }^{11}$ hepatoprotective, ${ }^{12}$ cytoprotective, ${ }^{13}$ antigenotoxic,,${ }^{14}$ antiinflammatory, ${ }^{15}$ antiulcerogenic, ${ }^{16}$ antipyretic, antifungal, ${ }^{17}$ antibacterial, ${ }^{18}$ antiviral, ${ }^{19}$ antiparasitic, ${ }^{20}$ antimutagenic, ${ }^{9}$ antioxidant, ${ }^{21}$ and anticancer activities, ${ }^{22-24}$ as well as stimulant and diuretic properties. ${ }^{25}$

The Pistacia atlantica subspecies kurdica, commonly known as Daraban or Qazwan tree in Kurdish ${ }^{26}$ and Baneh tree in Persian, is a medicinal and food plant that is native and endemic wild growing in Iran and in the Auramanat area of the Kurdistan province of Western Iran. ${ }^{27,28}$ The plant is also found in several temperate Asian countries including Armenia, Azerbaijan, Syria, Iraq, and Turkey. ${ }^{29-31}$ This Pistacia subspecies contains gums, particularly the well-known mastic gum, an oleo-resin obtained as exudate from the trunk, stem, and branches of the tree (Figure 1A). ${ }^{32}$

Mastic gum resin (MGR) has a long history as a therapeutic agent with many reported medicinal, pharmaceutical, and biological properties. ${ }^{5,33}$ Ancient Greeks used MGR for the treatment of various gastrointestinal ailments such as abdominal discomfort, stomach aches, gastralgia, dyspepsia, and peptic ulcers. ${ }^{34}$ MGR contains volatile oil with $\alpha$-pinenes, sabinene, and limonene as the main components, ${ }^{35,36}$ and was reported to possess significant in vitro antibacterial and antifungal properties. ${ }^{29}$ The resin is particularly effective against bacteria, such as Staphylococcus aureus, Escherichia coli, and Streptococcus pyogenes, that are resistant to common antimicrobial agents. ${ }^{17,18,37-39}$ MGR was shown to decrease the

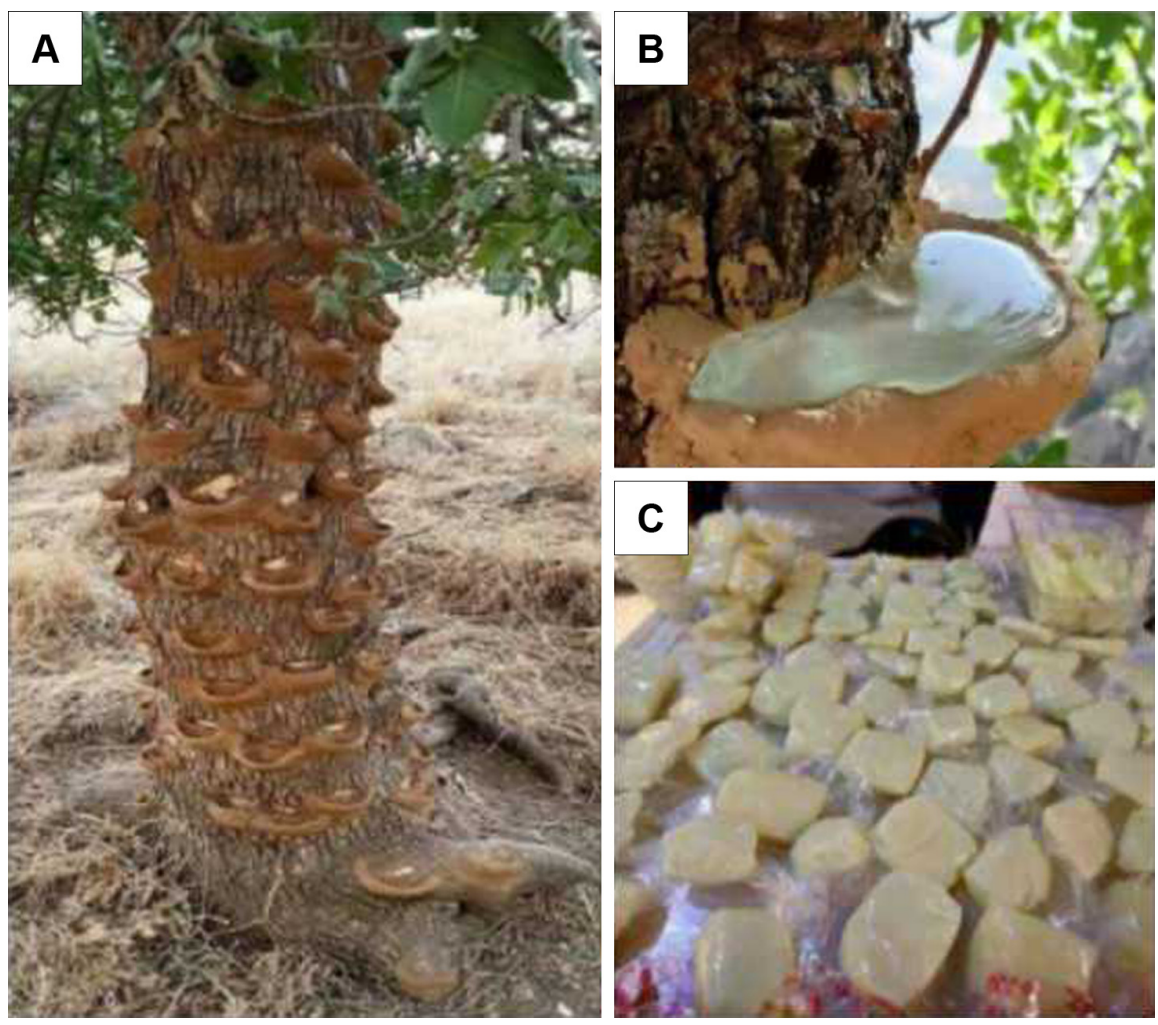

Figure I (A) Baneh or Daraban tree with clay cup for collecting resin. (B) The handmade muddy cup that was used for collecting exudate (resin). (C) Chewing gum produced from the natural MGR.

Abbreviation: MGR, mastic gum resin. 
plasma levels of interleukin 6 and C-reactive protein, ${ }^{36}$ suggesting that it may also act as an effective anti-inflammatory agent. In Kurdish culture, MGR is locally known as "bneshta tal" (Figure 1B), which is used for the treatment of many health ailments including hypertension, stomach pain, gastric ulcer, and wounds. ${ }^{31}$ In addition, MGR is used for making a natural Kurdish chewing gum (Figure 1C) without adding any additive, preservative, or colorant.

Although the MGR of Pistacia lentiscus var. chia seems to be potent at inhibiting the growth of several human cancers including prostate, ${ }^{40,41}$ colon, ${ }^{24}$ and colorectal cancers, leukemia, ${ }^{42}$ and Lewis lung carcinoma, ${ }^{43}$ the cytotoxicity of the MGR from $P$. atlantica subspecies kurdica on both cancerous and noncancerous cells has not been fully investigated. Thus, this study is the first to report the anticancer properties of the MGR from $P$. atlantica subspecies kurdica in several digestive system-related human cancer cell lines.

\section{Materials and methods Plant metabolite}

$P$. atlantica subspecies kurdica tree was identified based on the flora of the Iraq, ${ }^{37}$ and MGR was collected from the trees of Penjwen area, Kurdistan region, Northern Iraq, between June and August 2016, which corresponds to the period of peak oleoresin production by the plant (Figure 1B). The gum was obtained as exudate from the trunk and branches of the plant. About $10 \mathrm{mg}$ of the gum was suspended, just before use, in $1.0 \mathrm{~mL}$ of $0.2 \%(\mathrm{v} / \mathrm{v})$ Tween 80 in distilled water (vehicle) to obtain the gum solution. ${ }^{19}$

\section{Methods}

Phytochemical analysis

The total phenol and flavonoid contents in the MGR were determined by Folin-Ciocalteu ${ }^{44}$ and aluminum chloride $\left(\mathrm{AlCl}_{3}\right)$ colorimetric ${ }^{45}$ assays, respectively. For the phenolic content assessment, $1.0 \mathrm{~mL}$ of the exudate was mixed with $1.0 \mathrm{~mL}$ of 10 -fold diluted Folin-Ciocalteu reagent, vortexed well, and set aside for 5 minutes. Then, $10 \mathrm{~mL}$ of sodium carbonate solution $\left(\mathrm{Na}_{2} \mathrm{CO}_{3} ; 7.5 \%\right)$ was added, and the volume was made up to $25 \mathrm{~mL}$ with distilled water. After leaving the mixture for 60 minutes at room temperature, the absorbance was measured at $765 \mathrm{~nm}$ using a spectrophotometer (Hitachi, Chiyoda, Tokyo, Japan). Results were expressed in milligrams of gallic acid equivalent (GAE; 5-100 $\mu \mathrm{g} / \mathrm{mL}$ ) dissolved in distilled water per gram of exudate. On the other hand, for the flavonoid content evaluation, $1.0 \mathrm{~mL}$ of $2 \%$ $\mathrm{AlCl}_{3}$ in ethanol was mixed with the same volume of resin, and a drop of acetic acid was added. Then, the volume was made up to $25 \mathrm{~mL}$ using distilled water. After leaving the mixture for 45 minutes at room temperature, the absorbance was measured at $415 \mathrm{~nm}$ spectrophotometrically, and the results were expressed in milligrams of rutin equivalent $(\mathrm{RE}$; $5-25 \mu \mathrm{g} / \mathrm{mL}$ ) dissolved in ethanol per gram of exudate.

\section{Determination of antioxidant activity using free radical scavenging assay \\ DPPH assay}

Free radical scavenging activity of the MGR was determined using the DPPH reagent. ${ }^{21}$ Briefly, $0.5 \mathrm{~mL}$ of resin at various concentrations $(1,3,10,30$, and $100 \mu \mathrm{g} / \mathrm{mL})$ was added to $3.0 \mathrm{~mL}$ of DPPH solution $(0.1 \mathrm{mM})$ and incubated in the dark for 30 minutes. Later, the optical density (OD) was measured at $517 \mathrm{~nm}$ using the spectrophotometer. Results were expressed as inhibition \% of the DPPH. This assay was carried out in triplicate, and vitamin E (IndiaMart, Noida, India) was used as an internal control.

\section{ABTS+ assay}

ABTS reagent was used to measure the generated ABTS radicals. In brief, ABTS $(7 \mathrm{mM})$ reagent and potassium persulfate $(2.45 \mathrm{mM})$, at a ratio of $2: 1(\mathrm{v} / \mathrm{v})$, were mixed thoroughly and incubated in the dark for 16-18 hours at room temperature. Later, an equal volume of resin at various concentrations $(150,300,600,1,200$, and $2,400 \mu \mathrm{g} / \mathrm{mL})$ was mixed with a previously prepared solution containing ABTS radicals, incubated at $37^{\circ} \mathrm{C}$ for 1 hour, and read at $732 \mathrm{~nm}$ using the spectrophotometer in which glutathione (Sigma-Aldrich, St Louis, MO, USA) was used as a standard. ${ }^{46}$ The reading was used to determine the antioxidant activity of the resin.

\section{Determination of anticancer activity Cell culture}

The most common human cancer cell lines related to the digestive system, including bile duct cancer (cholangiocarcinoma) (KMBC), pancreatic carcinoma (PANC-1), gastric adenocarcinoma (CRL-1739), and colonic adenocarcinoma (COLO205), and normal human colon fibroblasts (CCD18Co) were purchased from the American Type Culture Collection (ATCC) (Manassas, VA, USA). The cells were propagated in various specific growth media - RPMI-1640 (ATCC) medium for COLO205 cells, DMEM (Thermo Fisher Scientific, Waltham, MA, USA) for PANC-1 cells, F-12K (Gibco) for CRL-1739 and KMBC cells, and EMEM (Gibco) for CCD-18Co cells - to which 10\% heat-inactivated FCS (Gibco), $100 \mathrm{U} / \mathrm{mL}$ penicillin, and $100 \mu \mathrm{g} / \mathrm{mL}$ streptomycin (Sigma-Aldrich) were added. As per the ATCC protocol, the cells were cultured and grown at $37^{\circ} \mathrm{C}$ in a humidified atmosphere of $95 \%$ air and $5 \% \mathrm{CO}_{2}$. The cultures were frequently 
examined for confluency and viability. Finally, cells were cultivated as monolayer cultures and examined for viability using Trypan Blue exclusion test.

\section{Cytotoxicity assay}

The antiproliferative effect of MGR on cancer and normal cells was quantified by MTT assay. ${ }^{47}$ Briefly, upon reaching $90 \%$ confluency, the cell concentration was determined using a hemocytometer counting chamber (Marienfeld, Lauda-Königshofen, Germany). Then, the cells, at $1 \times 10^{5}$ cells $/ \mathrm{mL}$, were cultured in 96-well microculture plates (TPP, Trasadingen, Switzerland) and treated with various concentrations of MGR in triplicates. MTT solution (Sigma-Aldrich) was added to the cells after incubation for 72 hours at $37^{\circ} \mathrm{C}$. After exactly 4 hours of incubation in the dark, MTT solubilization solution (Sigma-Aldrich) was added and the plate was allowed to stand for 5 minutes at room temperature. The OD was then measured at $570 \mathrm{~nm}$ using an ELISA plate reader (Biotech, Inc, Alpharetta, GA, USA). The $\mathrm{IC}_{50}$ value was determined from absorbance versus concentration curve and compared to that of doxorubicin, the commonly used antineoplastic agent (Sigma-Aldrich), and the negative control, 0.1\% DMSO (Sigma-Aldrich).

\section{Apoptosis detection assay}

The COLO205 cell death induced by MGR was investigated using the $\mathrm{AO} / \mathrm{PI}$ double-staining method based on the standard protocol and was viewed using confocal microscopy (Leica, Wetzlar, Germany). The COLO205 cells, at $1 \times 10^{6}$ cells $/ \mathrm{mL}$, were treated with MGR and incubated at $37^{\circ} \mathrm{C}$ under $5 \% \mathrm{CO}_{2}$ for 24,48 , and 72 hours. Then, the cells were trypsinized, collected, and centrifuged at $200 \times g$ (32R; Hettich, Tuttlingen, Germany) for 8 minutes, and the supernatant was removed. PBS was used to wash the cells twice after centrifuging at $200 \times g(32 \mathrm{R}$; Hettich) for $5 \mathrm{~min}$ utes, and excess medium was removed. About $15 \mu \mathrm{L}$ of the cell pellets was stained with $15 \mu \mathrm{L}$ mixture, containing equal amounts $(100 \mu \mathrm{g} / \mathrm{mL})$ of $\mathrm{AO}$ and PI mixture, for 3 minutes, and then, $15 \mu \mathrm{L}$ of stained cell suspension was placed on a glass slide, covered with a glass slip, and examined within 30 minutes before the fluorescence faded. ${ }^{48}$

\section{Annexin V-FITC assay}

COLO205 cell apoptosis caused by MGR treatment was determined with the annexin V-FITC kit (Sigma-Aldrich) without modifications. COLO205 cells, at $1 \times 10^{6}$ cells $/ \mathrm{mL}$, were treated with MGR at a concentration of $5.2 \pm 0.8 \mu \mathrm{g} / \mathrm{mL}$, while control cells were not treated. After 24, 48, and 72 hours of incubation, the treated cells were harvested by trypsinization and centrifuged at $200 \times g(32 \mathrm{R}$; Hettich) for 8 minutes.
Approximately $2 \mathrm{~mL}$ ice-cold PBS was used to wash the cell pellet twice before recentrifugation at $200 \times g$ for 8 minutes. The cells were resuspended in $0.5 \mathrm{~mL}$ ice-cold $1 \mathrm{X}$ binding buffer to which a mixture of $5 \mu \mathrm{L}$ of annexin V-FITC conjugate and $10 \mu \mathrm{L}$ of PI was added. The suspension was gently mixed by vortexing, allowed to stand in the dark at $25^{\circ} \mathrm{C}$ for 15 minutes, and then analyzed using a flow cytometer (BD FACSCalibur) equipped with an argon laser (BD Biosciences, San Jose, CA, USA) under laser-emitting excitation light at $488 \mathrm{~nm}$.

\section{Cell cycle assay}

The cytotoxic effect of MGR on COLO205 cells was further confirmed using cell cycle analysis by means of flow cytometry. In brief, approximately $2.5 \times 10^{6} \mathrm{COLO} 205 \mathrm{cells} / \mathrm{mL}$ treated with MGR at a concentration of $5.2 \pm 0.8 \mu \mathrm{g} / \mathrm{mL}$ were incubated for 24,48 , and 72 hours. The cells were harvested by trypsinization and centrifugation at $200 \times g(32 \mathrm{R}$; Hettich) for 5 minutes and washed with $1.0 \mathrm{~mL}$ ice-cold PBS (pH 7.4). To prevent cell clumping and aggregation, $500 \mu \mathrm{L}$ of $80 \%$ ice-cold ethanol was added to the cell pellet, gently mixed by vortexing, and then stored at $-20^{\circ} \mathrm{C}$. After $5-7$ days, the cells were washed twice with $1.0 \mathrm{~mL}$ PBS each time and centrifuged at $200 \times g(32 \mathrm{R}$; Hettich) for 5 minutes, and the ethanol was discarded. Finally, the cell pellets were stained with staining solution containing $0.1 \%$ Triton X-100, $10 \mathrm{mM}$ EDTA, $50 \mu \mathrm{g} / \mathrm{mL}$ RNAase A, and $3 \mu \mathrm{g} / \mathrm{mL}$ PI and incubated on ice in the dark for 30 minutes. The BD FACSCalibur flow cytometer equipped with argon laser (BD Biosciences) was used to analyze the cell suspension under laser-emitting excitation light at $488 \mathrm{~nm} .{ }^{49}$

\section{Caspase assays}

Caspase- 3 is the hallmark enzyme of apoptosis that is required for DNA fragmentation, while caspase-9 is an enzyme involved in the mitochondrial intrinsic pathway and precedes caspase-3. Thus, a colorimetric assay kit (GenScript, Piscataway, NJ, USA) was used to estimate the activities of caspase-3 and -9 in the COLO205 cells. COLO205 cells, at approximately $2 \times 10^{6}$ cells $/ \mathrm{mL}$, treated with MGR were incubated for 24, 48, and 72 hours; untreated cells which were similarly incubated served as controls. The cells were trypsinized and centrifuged for 5 minutes at 2,000 rpm (32R; Hettich). The medium was discarded, and the pellet was washed twice with ice-cold PBS and recentrifuged at 2,000 for 5 minutes. Approximately $50 \mu \mathrm{L}$ cold lysis buffer containing $0.5 \mu \mathrm{L}$ DTT and $0.25 \mu \mathrm{L}$ PMSF was used to lyse cells, and the cell suspension was allowed to stand on ice for exactly 60 minutes with vortexing at 10 -minute intervals. The cell lysates were centrifuged for 1 minute at 10,000 rpm (32R; Hettich) at $4{ }^{\circ} \mathrm{C}$, and the supernatant was collected for 
Table I Primer sequences in one-step SYBR Green quantitative real-time PCR

\begin{tabular}{lll}
\hline Primer & Forward sequence & Reverse sequence \\
\hline Bcl-2 & 5cl CCAGACTCATTCAACCAGACA-3A & 53A GATGACTGAGTACCTGAACCG-3T \\
Bax & 5ax TTTGCTACAGGGTTTCAT-3T & 53T CTCCATATTGCTGTCCAG-3C \\
Cyt-c & 5yt GTCTTATGCTTGCCTCCCTT-3C & 53C CGTCTGTCTTCGAGTCCGA-3T \\
B3T CGT & $53 T$ CGAGATGTGATGAAGGAGATG3-3A & 53A CCTGTTGACTGGTCATTACAA-3T \\
GAPDH & 5AP CGGGACCTAATGAAACTCCA-3G & 53G AATCTCCACTTTGCCACTGC-3T \\
\hline
\end{tabular}

Note: Highly purified salt-free primers were designed by Next Gene Scientific Sdn. Bhd. and synthesized by AITBiotech.

determination of protein concentrations using the Bradford assay. Then, $200 \mu \mathrm{g}$ protein in a $50 \mu \mathrm{L}$ solution was mixed with $50 \mu \mathrm{L} 2 \mathrm{X}$ reaction buffer containing $0.5 \mu \mathrm{L}$ DTT and $0.25 \mu \mathrm{L}$ PMSF. Approximately $5 \mu \mathrm{L}$ caspase substrate was added, and the suspension was transferred to a 96-well plate (TPP), wrapped with aluminum foil, and incubated in the dark at $37^{\circ} \mathrm{C}$ for 4 hours. Finally, the caspase activities were determined spectrophotometrically in a microplate reader (Universal Microplate Reader; Biotech, Inc) at $405 \mathrm{~nm}$.

\section{qRT-PCR assay}

RNeasy ${ }^{\circledR}$ lipid tissue mini kit (Qiagen NV, Venlo, the Netherlands) was used to extract total RNA from COLO205 cells prior to conducting qRT-PCR analysis. The nanophotometer (Implen GmbH, München, Germany) was used to quantify the RNA before aliquoting and storing at $-80^{\circ} \mathrm{C}$. The expression of Bax, Bcl-2, and Cyt-c genes was determined by qRTPCR assay using GAPDH and $\beta$-actin genes as references.

Highly purified salt-free primers were designed by Next Gene Scientific Sdn. Bhd. (Puchong, Malaysia) and synthesized by AITbiotech (Singapore, Singapore) (Table 1). QIAGEN $^{\circledR}$ One-Step RT-PCR SYBR Green kit (Qiagen NV) was used to prepare the reaction mix according to instructions of the manufacturer. Thermal cycler $\left(\mathrm{BioRad}^{\circledR}, \mathrm{CFX} 96\right.$; BioRad Laboratories, Inc., Hercules, CA, USA) amplification program conditions for temperature gradient PCR were as follows: $50^{\circ} \mathrm{C}$ for 10 minutes (reverse transcription), 1 cycle of $95^{\circ} \mathrm{C}$ for 5 minutes (initial activation), and 39 cycles of $95^{\circ} \mathrm{C}$ for 10 seconds (denaturation) and $50^{\circ} \mathrm{C}-60^{\circ} \mathrm{C}$ for 30 seconds (combined annealing and extension). The melting curve analysis was performed between 70 and $95^{\circ} \mathrm{C}$, with $0.5^{\circ} \mathrm{C} / 5$ seconds increments. CFX Manager ${ }^{\mathrm{TM}}$ software, version 1.6 (BioRad Laboratories, Inc.) was used for quantitative gene transcription analyses in triplicate. ${ }^{50}$

\section{Statistical analysis}

The data were expressed as mean \pm SD. Using SPSS software, version 21.0 (SPSS Inc., Chicago, IL, USA), the data were analyzed for significant differences at $P<0.05$. All experiments were done in triplicate.

\section{Results \\ MGR is rich in polyphenolic compounds}

The phytochemical investigation of the exudate revealed the presence of flavonoid and phenolic compounds. The total phenolic content was $147.11 \pm 0.25 \mathrm{mg} \mathrm{GAE} / \mathrm{g}$ extract, whereas the flavonoid content was $45.55 \pm 3.2 \mathrm{mg} \mathrm{RE} / \mathrm{g}$ extract, with $P=0.0004$ in both cases (Figure 2).

\section{MGR scavenged free radicals}

The antioxidant activity of the resin was evaluated by its ability to scavenge DPPH and ABTS+ free radicals. The resin showed DPPH scavenging activity with a percentage increase from 26.44, 60.37, 75.44, 83.66, and 95.56, respectively, at 1, 3, 10, 30, and $100 \mu \mathrm{g} / \mathrm{mL}$ (Figure 3A), with an $\mathrm{IC}_{50}$ value of $2.5 \mu \mathrm{g} / \mathrm{mL}$. In contrast, the resin exhibited ABTS+ radical scavenging activity with a percentage increase from $25.11,30.08,55.3,68.77$, and 89.9 at concentrations of 150 , $300,600,1,200$, and 2,400 $\mu \mathrm{g} / \mathrm{mL}$, respectively, with an $\mathrm{IC}_{50}$ value of $500 \mu \mathrm{g} / \mathrm{mL}$ (Figure 3B).

\section{MGR showed cytotoxicity toward cancer cells}

The colorimetric MTT assay was used to investigate the cytotoxic effects of the MGR on human bile duct cancer (cholangiocarcinoma) (KMBC), pancreatic carcinoma (PANC-1), gastric adenocarcinoma (CRL-1739), colonic

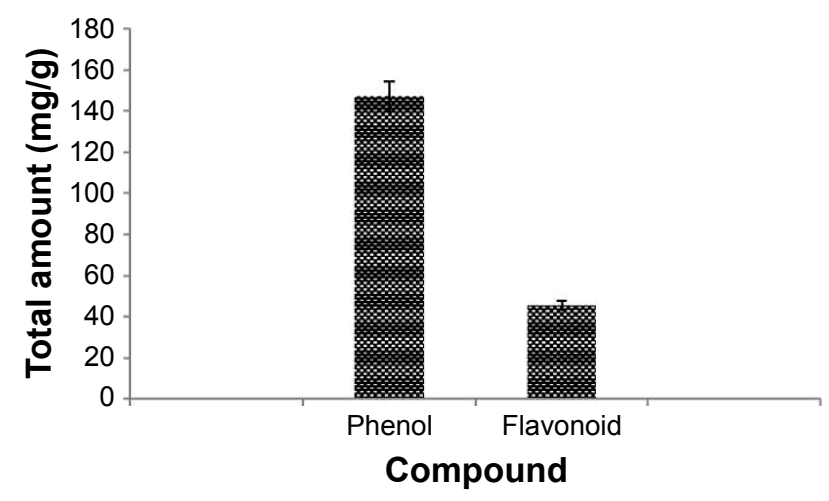

Figure 2 Total phenolic and flavonoid contents of MGR from Pistacia atlantica subspecies kurdica. Each value is the average of relative SD of 3 analyses. Abbreviation: MGR, mastic gum resin. 

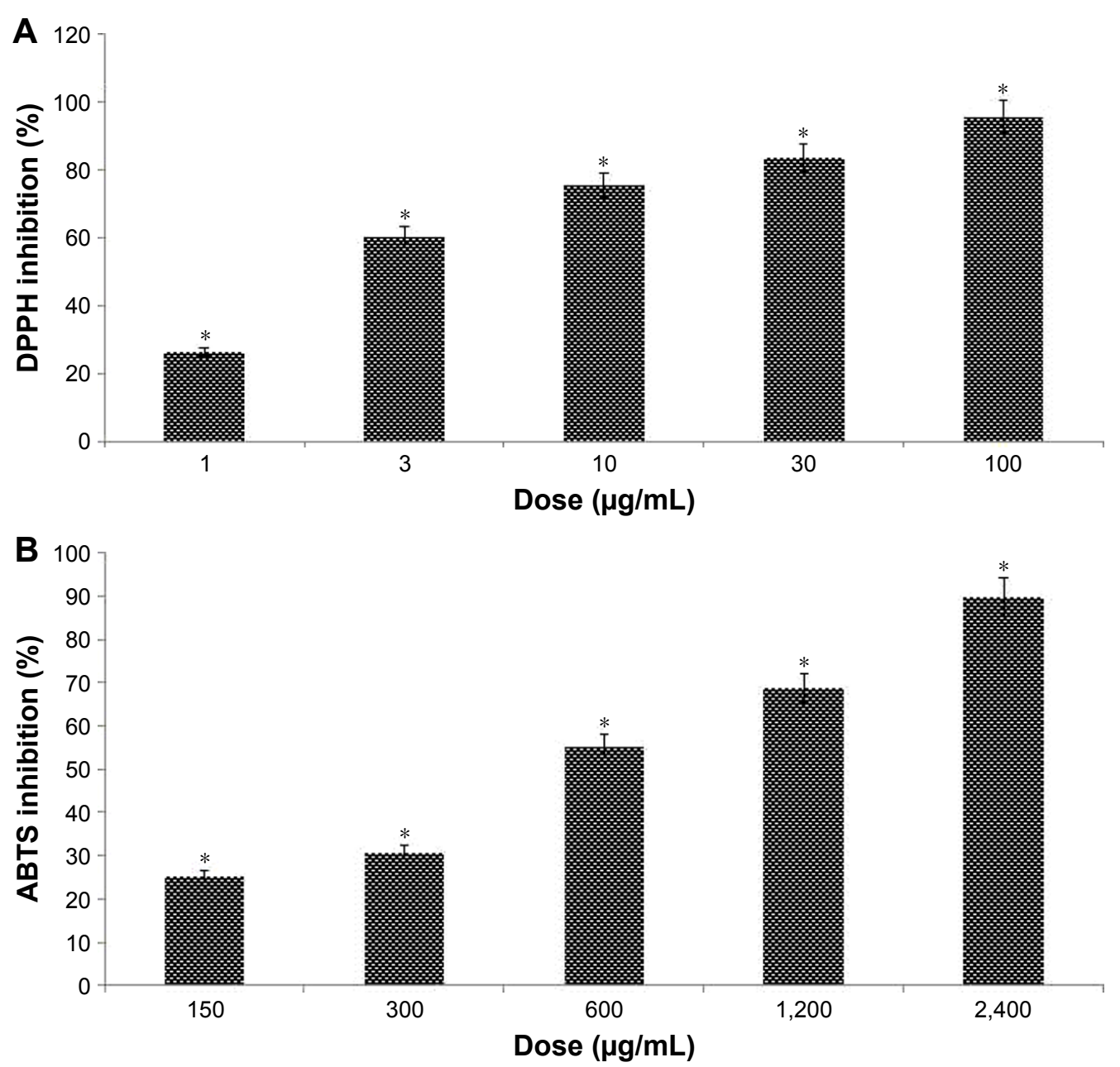

Figure 3 Increase in radical scavenging activity of MGR: (A) DPPH and (B) ABTS+. *Significant difference from control $(P<0.05)$. Abbreviation: MGR, mastic gum resin.

adenocarcinoma (COLO205), and normal human colon fibroblast (CCD-18Co) cells. The $\mathrm{IC}_{50}$ values were $15.34 \pm 0.21$, $11.52 \pm 0.18,8.11 \pm 0.23$, and $5.2 \pm 0.8 \mu \mathrm{g} / \mathrm{mL}$ at 72 hours of treatment for KMBC, PANC-1, CRL-1739, and COLO205 cells, respectively (Figure 4A). On the other hand, treatment with various doses of MGR did not adversely affect the normal CCD-18Co cells (Figure 4B). Thus, the results showed that MGR significantly inhibited proliferation of
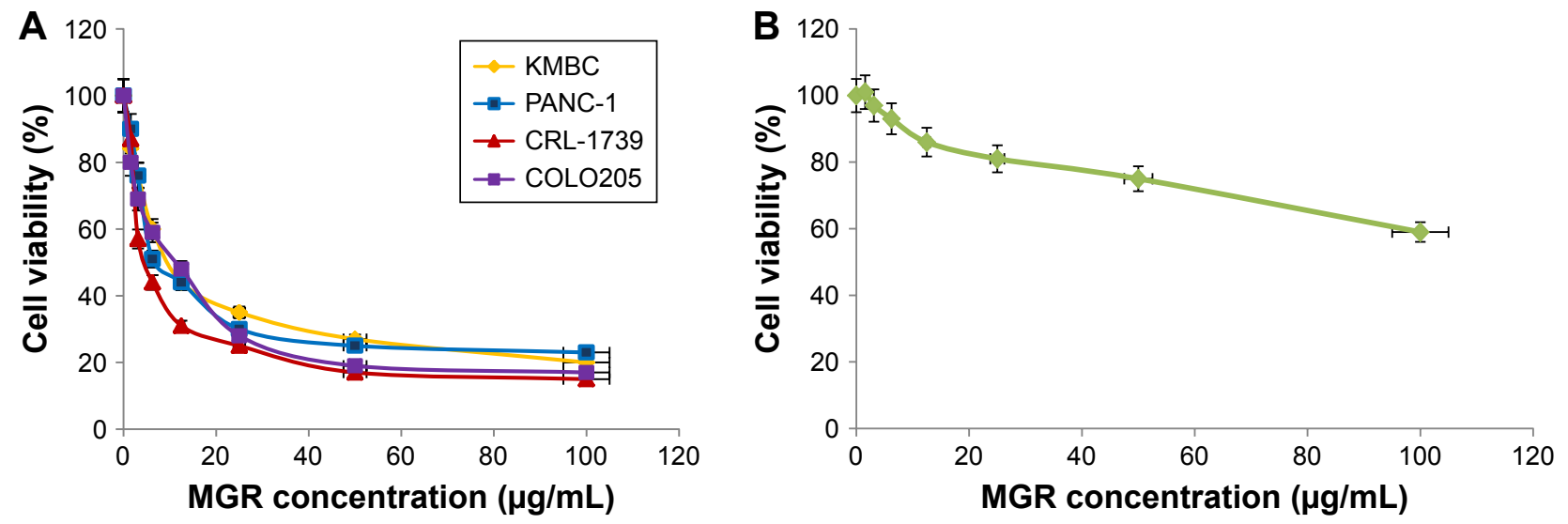

Figure $4(\mathrm{~A}) \mathrm{IC}_{50}$ value of $15.34 \pm 0.2 \mathrm{I}, \mathrm{I} \mathrm{I} .52 \pm 0.18,8.1 \mathrm{I} \pm 0.23$, and $5.2 \pm 0.8 \mu \mathrm{g} / \mathrm{mL}$ at 72 hours of treatment with MGR for bile duct cancer (cholangiocarcinoma) (KMBC), pancreatic carcinoma (PANC-I), gastric adenocarcinoma (CRL-1739), and colonic adenocarcinoma (COLO205) cells. (B) The normal human colon fibroblasts (CCD-I8Co) did not show any adverse effect after treatment with various doses of MGR.

Abbreviation: MGR, mastic gum resin. 
human cancerous cells while being innocuous to the normal fibroblasts. Based on MTT results, we used an $\mathrm{IC}_{50}$ of $5.2 \pm 0.8 \mu \mathrm{g} / \mathrm{mL}$ to further determine the antiproliferative activities of MGR on COLO205 cells.

\section{MGR induced apoptosis effects on colon cancer cells}

The effect of MGR on COLO205 cells was determined after treatment for 24, 48, and 72 hours, using AO/PI assay and confocal laser scanning microscopy. After 24 hours, the cells became apoptotic, which was evident by the development of membrane blebs. After 48 and 72 hours of treatment, the cells entered early and late apoptotic phases showing nuclear margination, chromatin condensation, and nuclear fragmentation or apoptotic body formation (Figure 5). These features indicated that MGR time-dependently reduced viability and caused the death of COLO205 cells. After treatment with MGR, normal human colon fibroblast CCD-18Co cells remained viable, normal in size and morphology, and with the regular cell membrane.

\section{MGR induced externalization of phosphatidylserine in colon cancer cells}

The effect of MGR on COLO205 cells was further determined by flow cytometry using the annexin V-FITC/PI apoptosis detection kit. The treatment caused a significant $(P<0.05)$ increase in the number of apoptotic cells with a consequential decrease in viable cells. Both early and late apoptotic cells increased with duration of treatment (Figure 6 and Table 2).

\section{MGR promoted cell cycle arrest at the G2/M phase in colon cancer cells}

MGR induced changes in COLO205 cell cycle phases (Figure 7). The cells mostly accumulated at the G2/M phase, which was particularly evident after 48 hours of treatment. After 72 hours of treatment, the cells significantly $(P<0.05)$ accumulated at the
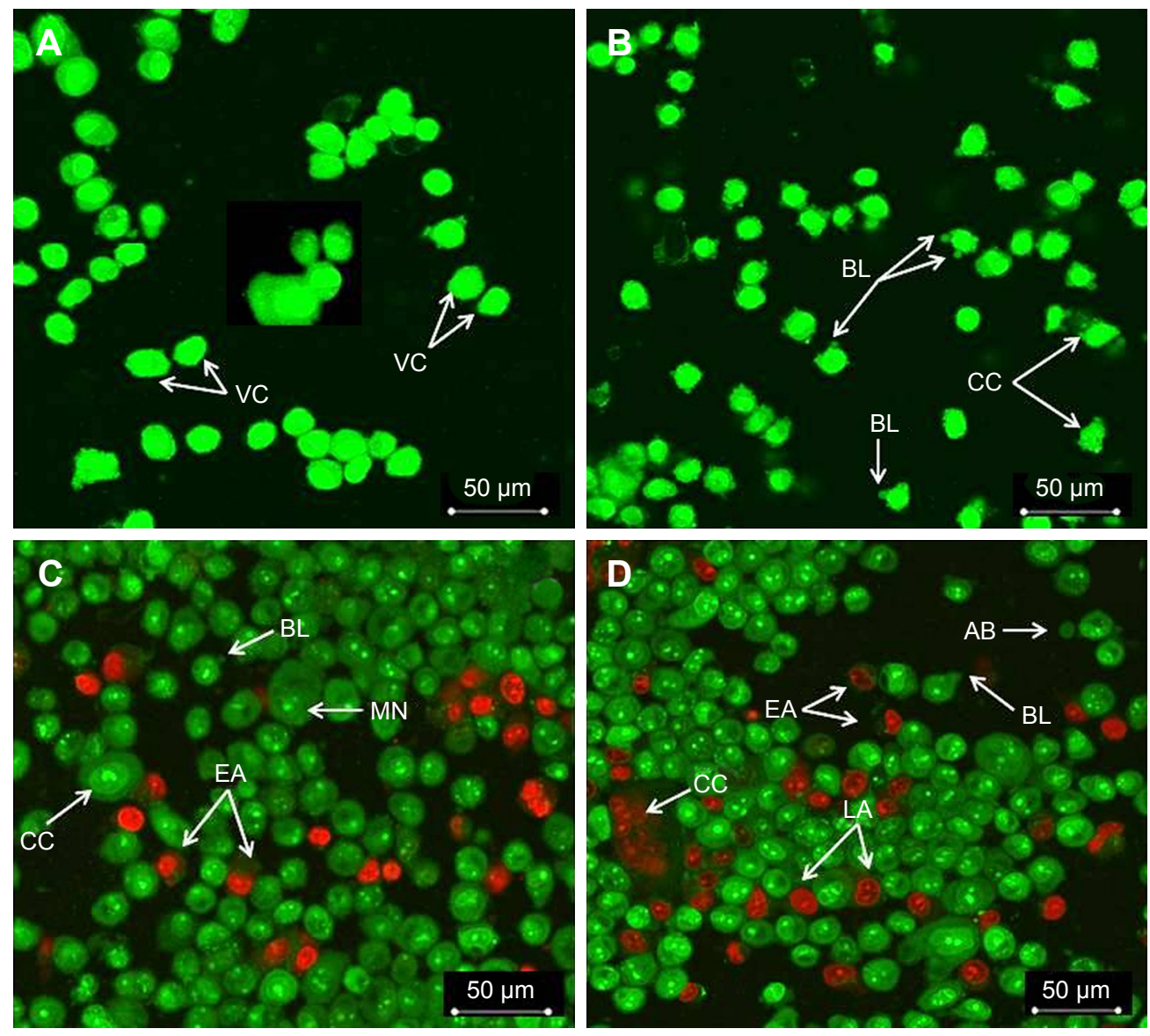

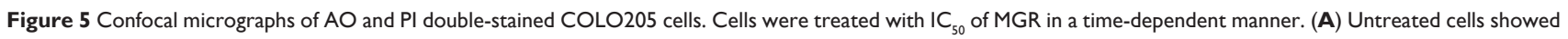
normal structure without prominent apoptosis and necrosis. (B) Early apoptosis features were seen after 24 hours representing intercalated AO (bright green) among the fragmented DNA. (C) BL and nuclear margination were noticeable after 48 hours of treatment (arrows). (D) Late apoptosis was seen after 72 hours of treatment (a positive staining of orange color represents the hallmark of late apoptosis).

Abbreviations: VC, viable cells; BL, blebbing; CC, chromatin condensation; MN, margination of the nucleus; EA, early apoptosis; AB, apoptotic body; LA, late apoptosis; MGR, mastic gum resin; PI, propidium iodide; $\mathrm{AO}$, acridine orange. 

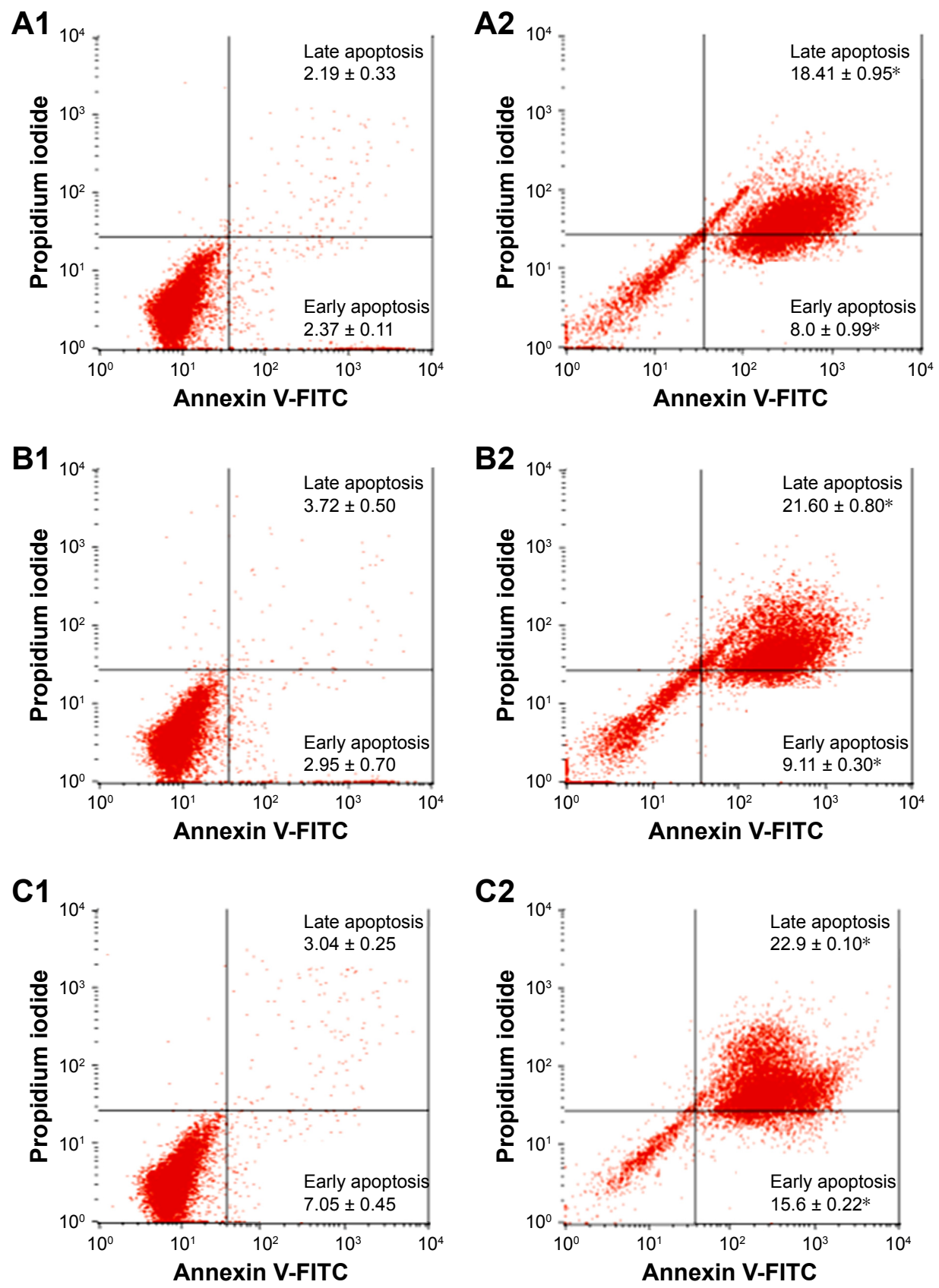

Figure 6 Induction of apoptosis in colonic adenocarcinoma (COLO205) cells by MGR which was observed by staining with FITC-conjugated annexin V-FITC. (AI-CI) Untreated (control) COLO205 cells at 24, 48, and 72 hours. (A2-C2) COLO205 cells after treatment with MGR at I2, 24, and 48 hours. *Significant (P< 0.05$)$ increase in apoptotic cells in the MGR-treated groups compared to untreated controls. Abbreviation: MGR, mastic gum resin.

Table 2 Flow cytometry analysis of COLO205 cells after treatment with MGR, for which the cells were stained with FITC-conjugated annexin- $\mathrm{V}$ and $\mathrm{PI}$ and incubated at $37^{\circ} \mathrm{C}$ for 24,48 , and 72 hours

\begin{tabular}{|c|c|c|c|c|c|c|}
\hline \multicolumn{7}{|l|}{ Cells (\%) } \\
\hline \multirow[t]{2}{*}{ Cell condition } & \multicolumn{2}{|l|}{24 hours } & \multicolumn{2}{|l|}{48 hours } & \multicolumn{2}{|l|}{72 hours } \\
\hline & Control & Treated & Control & Treated & Control & Treated \\
\hline Viable cells & $95.4 \pm 0.74$ & $71.59 \pm 0.65$ & $91.35 \pm 0.55$ & $69.28 \pm 0.15$ & $89.90 \pm 0.25$ & $61.5 \pm 0.13$ \\
\hline Early apoptosis & $2.37 \pm 0.11$ & $8.0 \pm 0.99 *$ & $2.95 \pm 0.70$ & $9.11 \pm 0.30 *$ & $7.05 \pm 0.45$ & $15.6 \pm 0.22 *$ \\
\hline Late apoptosis and/or necrosis & $2.19 \pm 0.33$ & $|8.4| \pm 0.95^{*}$ & $3.72 \pm 0.50$ & $21.6 \pm 0.80 *$ & $3.04 \pm 0.25$ & $22.9 \pm 0.10^{*}$ \\
\hline
\end{tabular}

Notes: Values are expressed as mean \pm SD of three different experiments. Data were analyzed using post hoc comparison test one-way ANOVA, and mean were compared by Tukey's $b$ test. *Significant $(P<0.05)$ increase in apoptotic cells in the MGR-treated groups compared to untreated controls.

Abbreviation: MGR, mastic gum resin. 

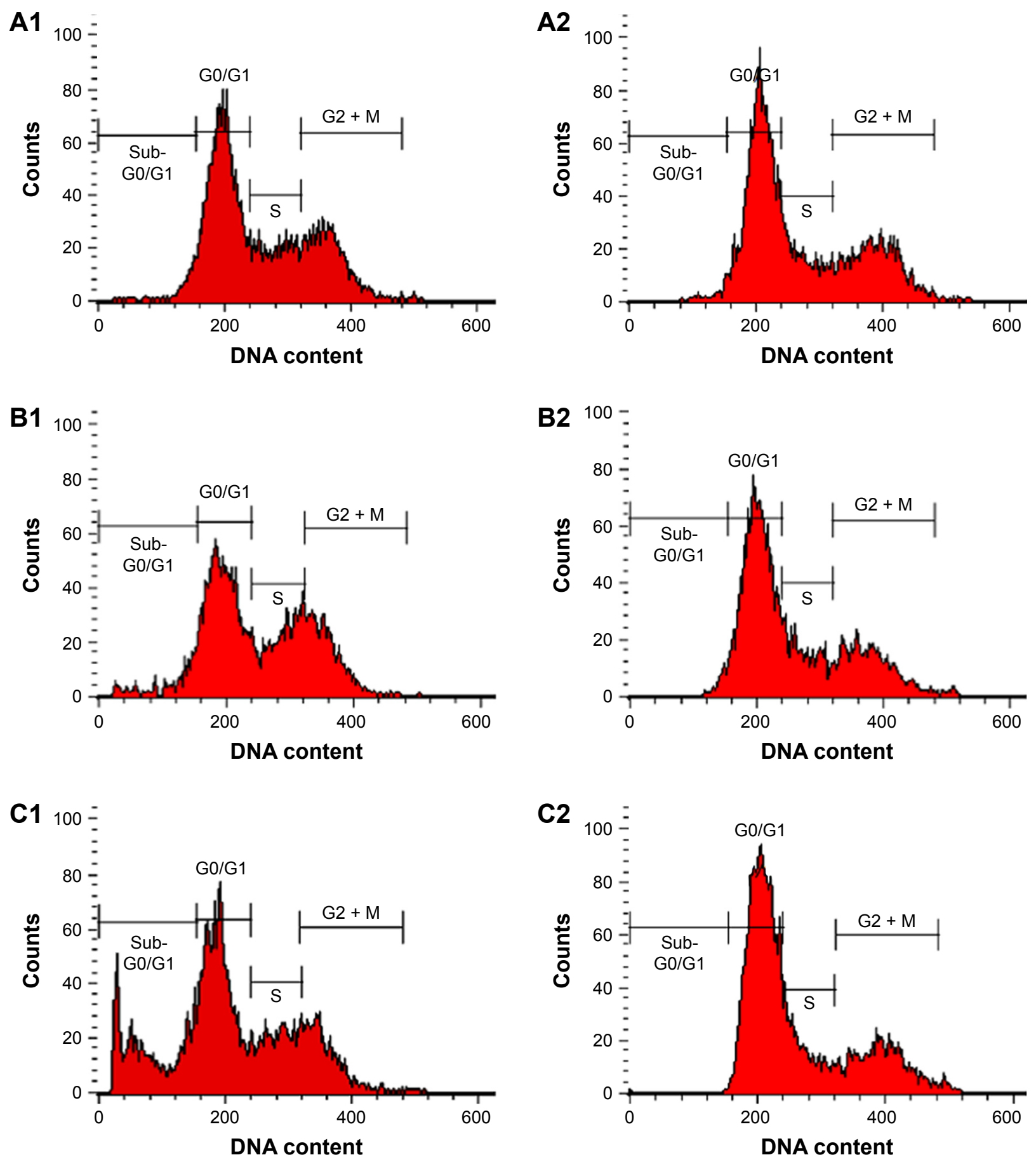

Figure 7 The cell cycle of colonic adenocarcinoma (COLO205) cells treated with MGR after staining with PI. (AI-CI) Untreated (control) COLO205 cells at 24, 48, and 72 hours. (A2-C2) COLO205 cells treated with resin at I2, 24, and 48 hours. G0/GI, G2/M, and S are cell cycle phases, and sub-G0/GI is the apoptotic cell population. Abbreviation: MGR, mastic gum resin.

G0/G1 phase while the sub-G0/G1 cells decreased in number. However, no significant change was observed in the S-phase cell population at all treatment periods (Table 3).

\section{MGR activated caspase- 3 and -9 in colon cancer cells}

The activities of caspase-3 and -9 in COLO205 cells treated with MGR are shown in Table 3. The treated cells significantly
$(P<0.05)$ expressed the caspases, and the expression increased with treatment period (Figure 8 and Table 4).

\section{MGR elicited gene expressions in colon} cancer cells

The qRT-PCR analysis was performed using the comparative threshold cycle method to determine gene expression normalized to GAPDH and $\beta$-actin as the reference 
Table 3 Flow cytometry analysis of COLO205 cells after treatment with MGR, for which the cells were stained with PI and incubated at $37^{\circ} \mathrm{C}$ for 24,48 , and 72 hours

\begin{tabular}{|c|c|c|c|c|c|c|}
\hline \multicolumn{7}{|l|}{ Cells (\%) } \\
\hline \multirow{2}{*}{$\begin{array}{l}\text { Cell cycle } \\
\text { phases }\end{array}$} & \multicolumn{2}{|l|}{24 hours } & \multicolumn{2}{|l|}{48 hours } & \multicolumn{2}{|l|}{72 hours } \\
\hline & Control & Treated & Control & Treated & Control & Treated \\
\hline G0/GI & $54.05 \pm 0.06$ & $43.70 \pm 0.45$ & $52.10 \pm 0.29$ & $54.61 \pm 0.52$ & $30.04 \pm 0.32$ & $45.70 \pm 0.68^{*}$ \\
\hline $\mathrm{G} 2 / \mathrm{M}$ & $10.65 \pm 0.76$ & $|8.00 \pm 0.4|^{*}$ & $13.96 \pm 0.26$ & $22.70 \pm 0.35^{*}$ & $14.30 \pm 0.22$ & $16.05 \pm 0.93 *$ \\
\hline Synthesis & $34.01 \pm 0.06$ & $37.30 \pm 0.33$ & $29.24 \pm 0.06$ & $20.93 \pm 0.12$ & $37.50 \pm 0.6 \mathrm{I}$ & $35.37 \pm 0.18$ \\
\hline Sub-G0/GI & $1.2 \pm 0.23$ & $1.00 \pm 0.20$ & $4.60 \pm 0.34$ & $1.80 \pm 0.20 *$ & $18.20 \pm 0.46$ & $2.85 \pm 0.56 *$ \\
\hline
\end{tabular}

Notes: Values are expressed as mean \pm SD of three different experiments. Data were analyzed using post hoc comparison test one-way ANOVA, and mean were compared by Tukey's $b$ test. *Significant $(P<0.05)$ increase in cells in sub-G0/GI phase in the MGR-treated groups compared to untreated controls.

Abbreviation: MGR, mastic gum resin.

housekeeping genes. As shown in Figure 9, the proapoptotic Bax gene in the COLO205 cells was upregulated 1.66-fold by MGR treatment whereas the antiapoptotic Bcl-2 and Cyt-c genes were downregulated 1.21 -fold and 1.33 -fold, respectively.

\section{Discussion}

Plants constitute an important source of active natural compounds such as phenols and flavonoids, which differ widely in terms of structure and biological properties. They play a remarkable role in the traditional medicine in different countries, especially in the prevention of cancer, hypertension, diabetes, and cardiovascular diseases. ${ }^{4,6}$

The protective effects of plants can be due to the presence of flavonoids and phenolic compounds. The main phytochemicals in the Pistacia spp. are gallic acid, quercetin, 1,2,3,4,6-pentagalloyl glucose, and $\alpha$-tocopherol. In this current study, it is confirmed that the Baneh extract contains more polyphenols and flavonoids than the extracts of many

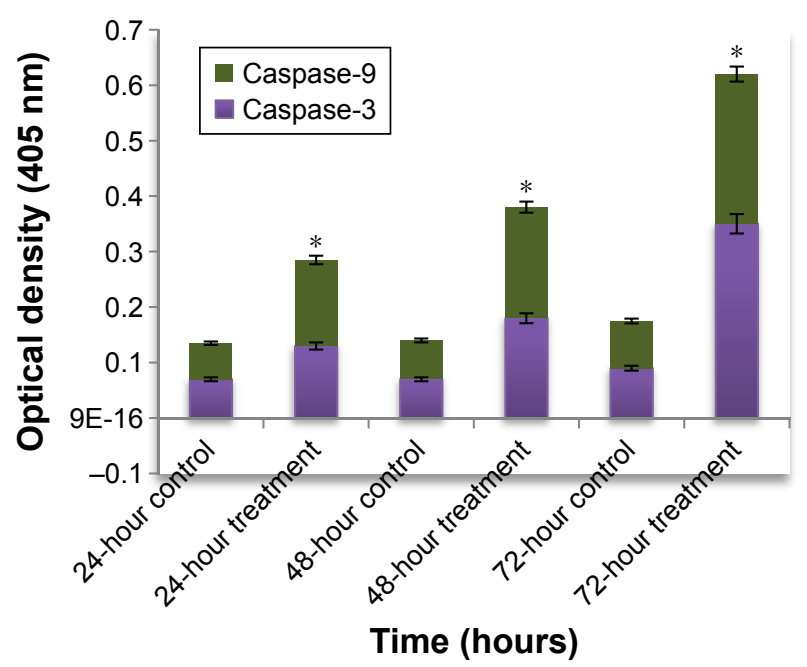

Figure 8 Activities of caspase-3 and -9. The total cell lysates from COLO205 cells treated with MGR for 24,48 , and 72 hours were analyzed using caspase colorimetric protease assay kits. *Significant difference from control $(P<0.05)$. Abbreviation: MGR, mastic gum resin. plants belonging to the same genus including Pistacia terebinthus, $P$. lentiscus fruits, ${ }^{21}$ and $P$. atlantica Desf. leaf extracts. ${ }^{8}$ Since phenolic compounds have good antioxidant and radical scavenging properties, ${ }^{51}$ the Baneh extract rich in these compounds has the potential to be developed into a natural antioxidant.

Antioxidants have attracted much interest with respect to their protective effect against free-radical damage that may be the cause of many diseases including cancer, and these compounds have been shown to inhibit cancer cell growth through cell cycle arrest and activation of apoptosis. ${ }^{52}$ In this study, the antioxidant activities of MGR were evaluated by measuring the generated free radicals using DPPH and ABTS assays, and the results were in agreement with previously conducted researches on the various species of the genus Pistacia. ${ }^{8,9,13,21}$

Over the past 2 decades, cancer treatment has evolved from using relatively nonspecific cytotoxic agents to compounds of greater selectivity and specificity. Many of the cancer therapeutics are obtained from plants. Plants belonging to the genus Pistacia are considered as the most popular medicinal plants worldwide, including the Iraqi Kurdistan region. ${ }^{18}$ The antioxidant and anti-inflammatory properties of various parts of Pistacia tree including fruit, leaves, volatile oil, resin, and gum have been determined. ${ }^{21}$ Recent studies have shown that these portions of the tree also have potential anticancer effects, inducing cytotoxicity in several tumor cell lines, such as Lewis lung carcinoma (LLC) cells, mouse skin melanoma (B16F10) cells, human lung cancer (H292) cells, ${ }^{13}$ human breast cancer (MCF-7) cells,${ }^{54}$ human melanoma (Skmel-28 and Mewo) cells, human oral cancer (YD-10B) cells, ${ }^{23}$ human leukemia (K562) cells, ${ }^{55}$ human prostate cancer (PC-3) cells, ${ }^{40}$ and human colon carcinoma (HCT116 and HT29) cells. ${ }^{52,56}$

The antiproliferative effect of MGR seems to be specific to cancer cells. The resin did not affect the viability of normal 
Table 4 Spectrophotometric analysis of caspases in COLO205 cells after treatment with MGR for 24, 48, and 72 hours

\begin{tabular}{|c|c|c|c|c|c|c|}
\hline \multicolumn{7}{|l|}{ Cells (\%) } \\
\hline \multirow[t]{2}{*}{ Caspase } & \multicolumn{2}{|l|}{24 hours } & \multicolumn{2}{|l|}{48 hours } & \multicolumn{2}{|l|}{72 hours } \\
\hline & Control & Treated & Control & Treated & Control & Treated \\
\hline Caspase-3 & $0.058 \pm 0.020$ & $0.12 \pm 0.02 *$ & $0.073 \pm 0.04 I$ & $0.18 \pm 0.07 *$ & $0.099 \pm 0.032$ & $0.21 \pm 0.06 *$ \\
\hline Caspase-9 & $0.07 \pm 0.06 \mathrm{I}$ & $0.16 \pm 0.03 *$ & $0.074 \pm 0.01$ & $0.19 \pm 0.05^{*}$ & $0.09 \pm 0.02$ & $0.25 \pm 0.035^{*}$ \\
\hline
\end{tabular}

Notes: Values are expressed as mean \pm SD of three different experiments. Data were analyzed using post hoc comparison test one-way ANOVA, and mean were compared by Tukey's $b$ test. *Significant $(P<0.05)$ increase in apoptotic cells in the MGR-treated groups compared to untreated controls.

Abbreviation: MGR, mastic gum resin.

fibroblasts. At 72-hour $\mathrm{IC}_{50}$ of $5.2 \pm 0.8 \mu \mathrm{g} / \mathrm{mL}$, the antiproliferative effect of MGR on human colonic adenocarcinoma COLO205 cells was very potent. The resin causes cancer cell apoptosis in a time-dependent manner, increasing the effect with the time of exposure. On the other hand, recently Rahbar Saadat et $\mathrm{al}^{57}$ reported that after 24 hours of treatment with $P$. atlantica MGR, cytotoxicity was induced in a dose-dependent manner with an $\mathrm{IC}_{50}$ of about 182,215 , and $90 \mu \mathrm{g} / \mathrm{mL}$ for NIH-3T3 cells, KB cells, and HUVEC cells, respectively.

Cell cycle analysis showed MGR affects G1 checkpoint and arrests cells at the G2/M phase, particularly after 48 hours of treatment. There was also a significant decrease in COLO205 cells at the sub-G0/G1 phases with resin treatment, possibly as a result of elimination through apoptosis.

Although the anticancer effect of MGR was obvious, the molecular mechanism of the effect is still not clear. A previous study showed that the antiprostate cancer effect of MGR is exhibited through targeting of NF- $\mathrm{\kappa B}$ signaling pathway. ${ }^{40}$ MGR also showed antiprostate cancer effect on LNCaP and PC-3 cells by suppressing the expression and function of $P S A$ and $h K 2$ promoter genes in the androgen receptor. ${ }^{41,58}$

It is suggested that the cancer cell antiproliferative effect is mediated via simultaneous upregulation of proapoptotic genes and downregulation of antiapoptotic genes. The proapoptotic Bax protein in the endoplasmic reticulum membrane upon stimulation undergoes conformational changes, causing the release of calcium into cytoplasm and activation of mCalpain. ${ }^{59}$ Additionally, the upregulation of Bax triggered a release of cytochrome $\mathrm{c}$ from mitochondria and induced caspase activation into the cytosols. Several studies had suggested that Bax could reduce the mitochondrial membrane potential by creating pores in the membrane for cytochrome c to escape and eventually cause cell death. Moreover, the release of cytochrome c was upstream of the initiation of caspase cascade including caspase- 3 and -9 in

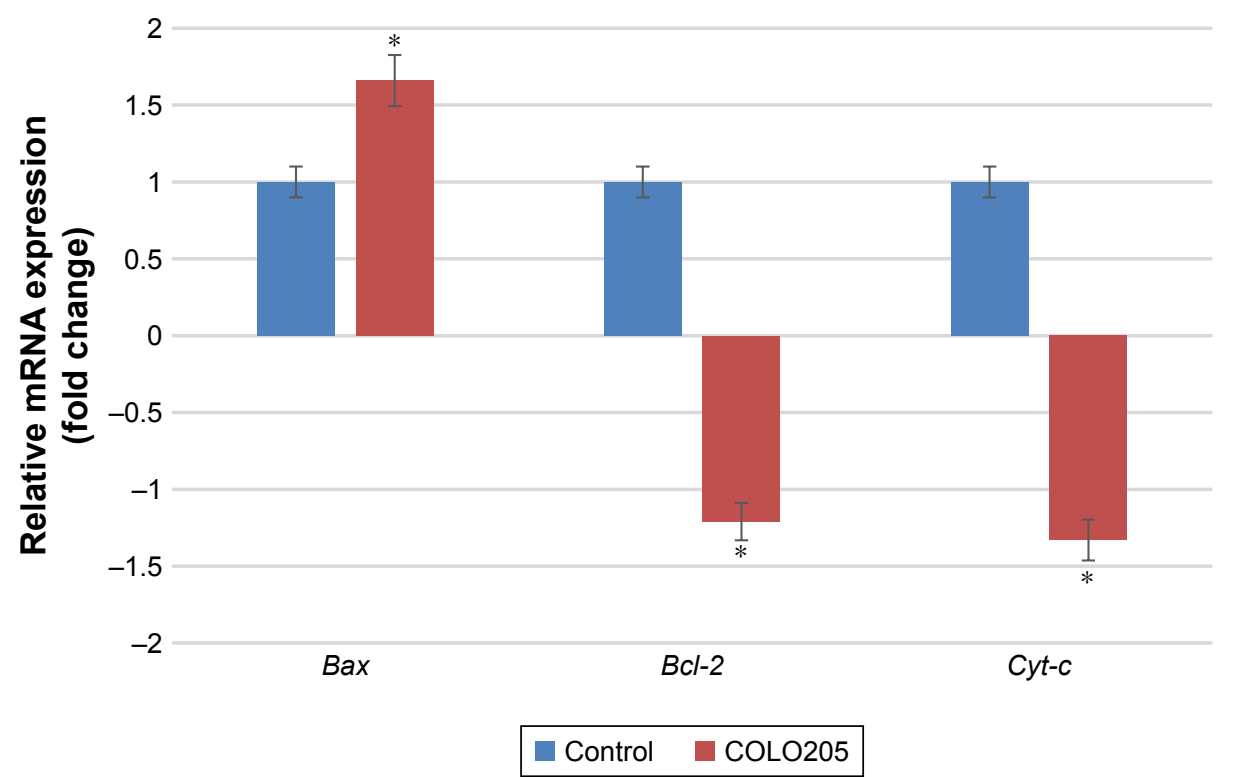

Figure 9 mRNA expression levels of $B C l-2$, Bax, and Cyt-c normalized to the transcription levels of $\beta$-actin and GAPDH. The qRT-PCR analysis was performed on COLO205 cells treated with $5.2 \pm 0.8 \mu \mathrm{g} / \mathrm{mL}$ MGR. The experiment was done in triplicates, and data are expressed as mean \pm SD. $*$ Significant difference from control $(P<0.05)$. Abbreviations: MGR, mastic gum resin; qRT-PCR, quantitative real-time polymerase chain reaction. 

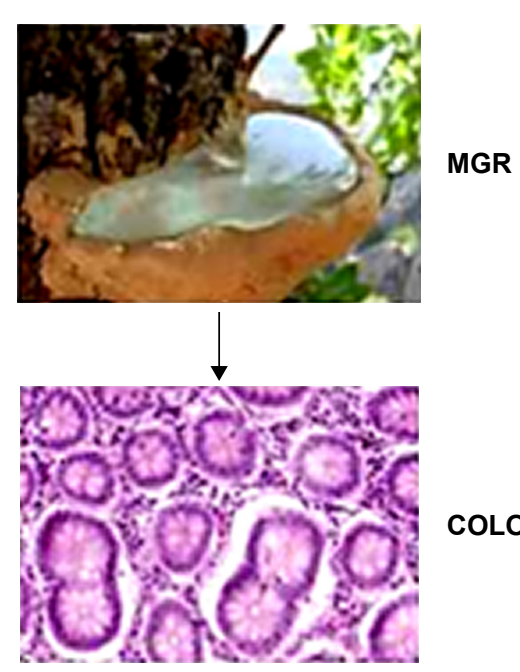

COLO205 cells
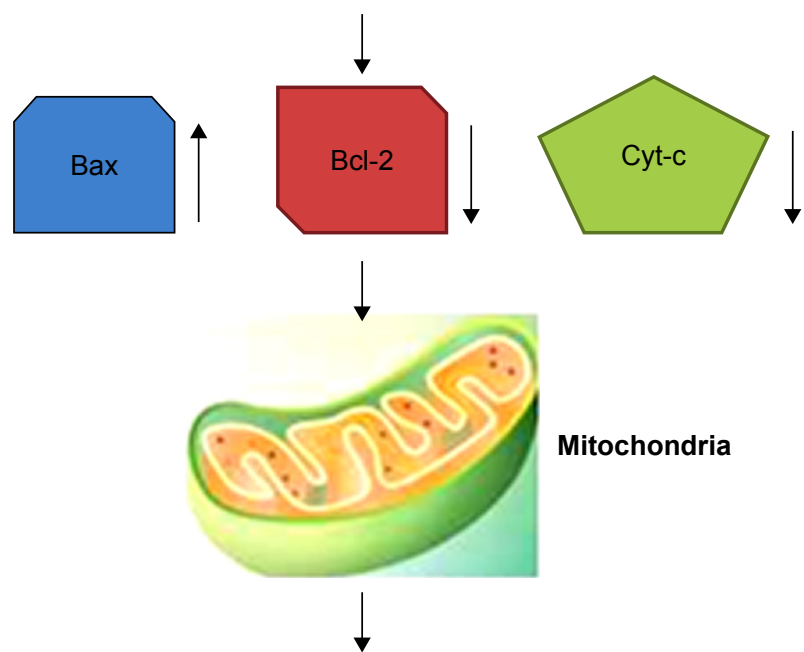

Mitochondria
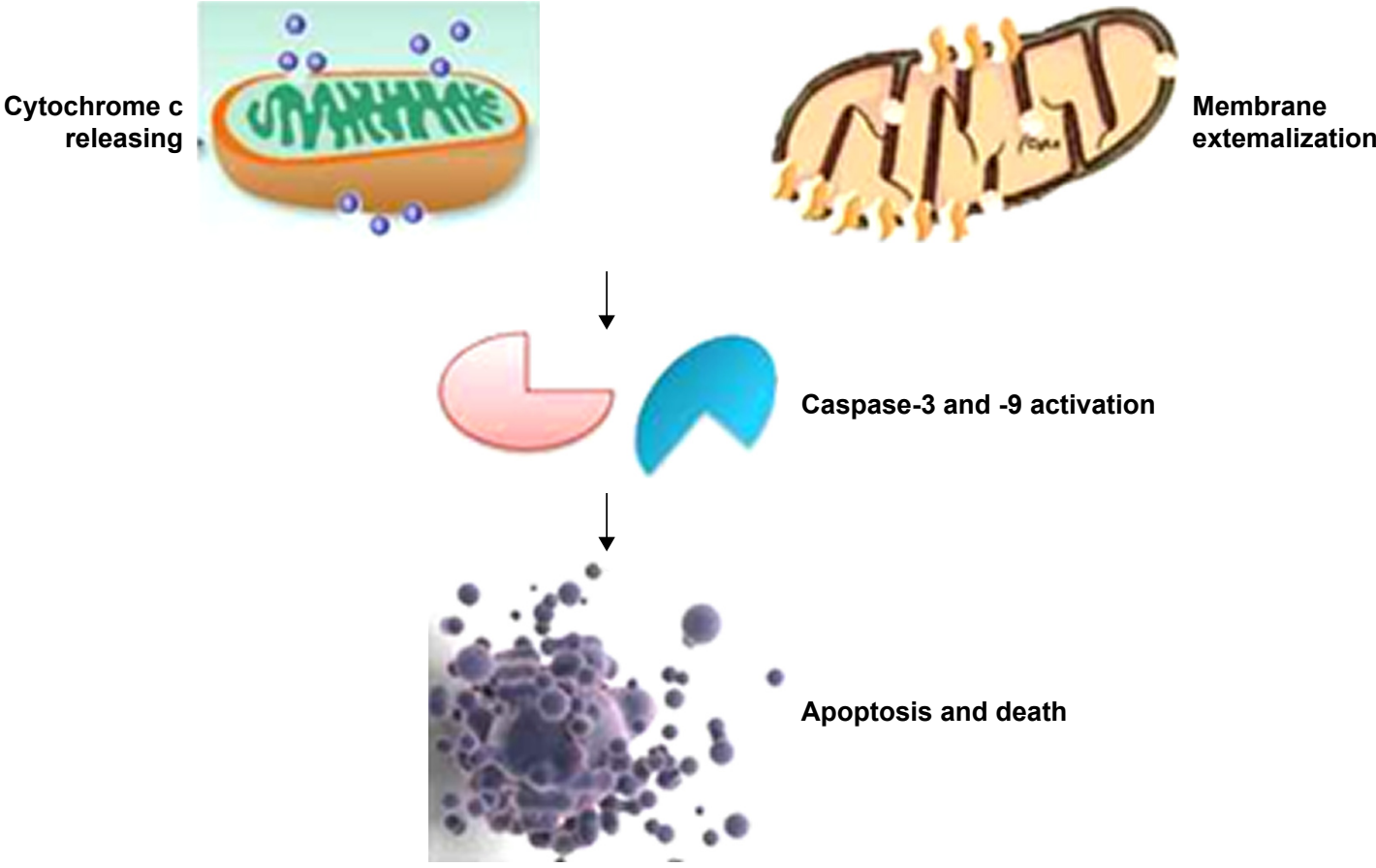

Apoptosis and death

Figure 10 Proposed model of MGR mechanism of action behind its antiproliferative and apoptosis effects against colon adenocarcinoma in vitro. Abbreviation: MGR, mastic gum resin. 
enhanced apoptosis. In this study, cytochrome $\mathrm{c}$ is released into the cytoplasm to stimulate the apoptosome consisting of Apaf1, ATP, and procaspase 9. Activation of procaspase 9 leads to activation of caspase-3, followed by DNA fragmentation and cell death. ${ }^{60,61}$ Interestingly, this study showed that MGR upregulated the proapoptotic Bax while downregulated the antiapoptotic Bcl-2 gene. This shows that antihuman colonic adenocarcinoma effect of MGR is through activation of the mitochondrial pathway of apoptosis (intrinsically triggered cell death) (Figure 10).

\section{Conclusion}

The present study demonstrated that MGR induced human colon cancer toxicity and apoptosis in vitro in a timedependent manner through the mitochondrial apoptosis pathway. Thus, MGR can potentially be developed into a safe product for the treatment of colon cancers, although some people in the middle east use it daily as a chewing gum to protect themselves from digestive diseases, especially colon cancer. Nonetheless, a further in-depth analysis will be done in our future study through in vivo experiments to test this hypothesis and also to investigate further roles of MGR as a potential anticancer agent.

\section{Acknowledgments}

The author is grateful to the staff of Universiti Putra Malaysia and the University of Sulaimani for their cooperation and technical assistance. The special fund for this research was obtained from MOSTI (grant no. 5495308).

\section{Disclosure}

The author reports no conflicts of interest in this work.

\section{References}

1. Rahman HS, Rasedee A, Abdul AB, et al. Zerumbone-loaded nanostructured lipid carrier induces G2/M cell cycle arrest and apoptosis via mitochondrial pathway in a human lymphoblastic leukemia cell line. Int J Nanomedicine. 2014;9:527-538.

2. Kazemi M, Eshraghi A, Yegdaneh A, Ghannadi A. Clinical pharmacognosy, a new interesting era of pharmacy in the third millennium. Daru. 2012;20(1):18.

3. Sharifi MS, Hazell SL. Isolation, analysis and antimicrobial activity of the acidic fractions of mastic, kurdica, mutica and cabolica gums from genus Pistacia. Glob J Health Sci. 2012;4(1):217-228.

4. Kumar M, Kaur V, Kumar S, Kaur S. Phytoconstituents as apoptosisinducing agents: the strategy to combat cancer. Cytotechnology. 2016; 68(4):531-563.

5. Giaginis C, Theocharis S. Current evidence on the anticancer potential of Chios mastic gum. Nutr Cancer. 2011;63(8):1174-1184.

6. Ben Douissa F, Hayder N, Chekir-Ghedira L, et al. New study of the essential oil from leaves of Pistacia lentiscus L. (Anacardiaceae) from Tunisia. Flavour Fragr J. 2005;20:410-414.
7. Aghaei P, Bahramnejad B, Mozafari AA. Effect of different plant growth regulators on callus induction of stem explants in Pistacia atlantica subspecies kurdica. Plant Knowledge J. 2013;2(3):108.

8. Gourine N, Yousfi M, Bombarda I, Nadjemi B, Gaydou E. Seasonal variation of chemical composition and antioxidant activity of essential oil from Pistacia atlantica Desf. leaves. J Am Oil Chem Soc. 2010; 87(2):157-166.

9. Peksel A, Arisan-Atac I, Yanardag R. Evaluation of antioxidant and antiacetylcholinesterase activities of the extracts of Pistacia atlantica Desf. leaves. J Food Biochem. 2010;34(3):451-476.

10. Dedoussis GVZ, Kaliora AC, Psarras S, et al. Antiatherogenic effect of Pistacia lentiscus via GSH restoration and downregulation of CD36 mRNA expression. Atherosclerosis. 2004;174(2):293-303.

11. Hamdan II, Afifi FU. Studies on the in vitro and in vivo hypoglycemic activities of some medicinal plants used in the treatment of diabetes in Jordanian traditional medicine. J Ethnopharmacol. 2004;93(1):117-121.

12. Ljubuncic P, Song H, Cogan U, Azaizeh H, Bomzon A. The effects of aqueous extracts prepared from the leaves of Pistacia lentiscus in experimental liver disease. J Ethnopharmacol. 2005;100(1):198-204.

13. Remila S, Atmani-Kilani D, Delemasure S, et al. Antioxidant, cytoprotective, anti-inflammatory and anticancer activities of Pistacia lentiscus (Anacardiaceae) leaf and fruit extracts. Eur J Integr Med. 2015; 7(3):274-286

14. Bhouri W, Derbel S, Skandrani I, et al. Study of genotoxic, antigenotoxic and antioxidant activities of the digallic acid isolated from Pistacia lentiscus fruits. Toxicol In Vitro. 2010;24(2):509-515.

15. Minaiyan M, Karimi F, Ghannadi A. Anti-inflammatory effect of Pistacia atlantica subspecies kurdica volatile oil and gum on acetic acidinduced acute colitis in the rat. Res J Pharmacogn. 2015;2(2):1-12.

16. Dellai A, Souissi H, Borgi W, Bouraoui A, Chouchane N. Antiinflammatory and antiulcerogenic activities of Pistacia lentiscus L. leaves extracts. Ind Crops Prod. 2013;49:879-882.

17. Tassou CC, Nychas GJE. Antimicrobial activity of the essential oil of mastic gum (Pistacia lentiscus var. chia) on gram positive and gram negative bacteria in broth and model food system. Int Biodeterior Biodegradation. 1995;36:411-420.

18. Pirbalouti AG, Malekpoor F, Hamedi B. Ethnobotany and antimicrobial activity of medicinal plants of Bakhtiari Zagross mountains, Iran. J Med Plants Res. 2012;6(5):675-679.

19. Taran M, Mohebali M, Esmaeli J. In vivo efficacy of gum obtained Pistacia atlantica in experimental treatment of cutaneous leishmaniasis. Iran J Public Health. 2010;39(1):36-41.

20. Azaizeh H, Halahleh F, Abbas N, et al. Polyphenols from Pistacia lentiscus and Phillyrea latifolia impair the exsheathment of gastrointestinal nematode larvae. Vet Parasitol. 2013;191(1):44-50.

21. Abdelwahed A, Bouhlel I, Skandrani I, et al. Study of antimutagenic and antioxidant activities of gallic acid and 1, 2, 3, 4, 6-pentagalloylglucose from Pistacia lentiscus: confirmation by microarray expression profiling. Chem Biol Interact. 2007;165(1):1-13.

22. Dimas KS, Pantazis P, Ramanujam R. Chios mastic gum: a plantproduced resin exhibiting numerous diverse pharmaceutical and biomedical properties. In Vivo. 2012;26(5):777-785.

23. Li S, Cha I, Nam W. Chios mastic gum extracts as a potent antitumor agent that inhibits growth and induces apoptosis of oral cancer cells. Asian Pac J Cancer Prev. 2011;12(7):1877-1880.

24. Yemmen M, Nguyen PH, Ayadi MT, Mégraud F, Varon C. Antiproliferative and proapoptotic effects of leaf, fruit and stem extracts of Pistacia lentiscus on human colon and gastric cancer cell lines. Int J Adv Pharm Biol Chem. 2015;4(4):737-745.

25. Mozaffarian V. Flora of Iran: Compositae: Anthemideae \& Echinopeae. Tehran: Research Institute of Forests and Rangelands; 2008.

26. Dyary HO, Rahman HS, Othman HH, Hassan SMA, Abdullah R. Acute toxicity of Pistacia atlantica green seeds on Sprague-Dawley rat model. J Zankoy Sulaimani. 2017;19(3-4):9-16.

27. Amin Gh. The Most Common Traditional Medicinal Plants in Iran. Tehran: Tehran University of Medical Sciences, Research Services; 2005. 
28. Amiri MS, Jabbarzadeh P, Akhondi M. An ethnobotanical survey of medicinal plants used by indigenous people in Zangelanlo district, Northeast Iran. J Med Plants Res. 2012;6(5):749-753.

29. Hesami G, Hesami S, Fatemi A. Effect of Pistacia atlantica subsp. Kurdica essential oil and acetic acid on Botrytis cinerea growth in culture media, grape and cucumber fruits. Int J Microbiol Mycol. 2013;1(2): $13-21$.

30. Gkogka E, Hazeleger WC, Beumer RR, editors. Antimicrobial activity of the essential oil of mastic gum (Pistacia lentiscus var. Chia). In: Programme and abstracts of the 21st International ICFMH Symposium, Evolving Microbial Food Quality and Safety; September 1-4, 2008; Aberdeen.

31. Mati E, de Boer H. Ethnobotany and trade of medicinal plants in the Qaysari Market, Kurdish Autonomous Region, Iraq.J Ethnopharmacol. 2011;133(2):490-510.

32. Dogan O, Baslar S, Aydin H, Mert HH. A study of the soil-plant interactions of Pistacia lentiscus L. distributed in the western Anatolian part of Turkey. Acta Bot Croat. 2003;62(2):73-88.

33. Demirci F, Baser KHC, Calis I, Gokhan E. Essential oil and antimicrobial evaluation of the Pistacia eurycarpa. Chem Nat Compd. 2001; 37(4):332-335.

34. Al-Said MS, Ageel A, Parmar NS, Tariq M. Evaluation of mastic, a crude drug obtained from Pistacia lentiscus for gastric and duodenal anti-ulcer activity. J Ethnopharmacol. 1986;15:271-278.

35. Magiatis P, Melliou E, Skaltsounis AL, Chinou IB, Mitaku S. Chemical composition and antimicrobial activity of the essential oils of Pistacia lentiscus var. chia. Planta Medica. 1999;65(08):749-752.

36. Sharifi MS, Hazell SL. GC-MS analysis and antimicrobial activity of the essential oil of the trunk exudates from Pistacia atlantica kurdica. J Pharm Sci Res. 2011;3(2):1364-1367.

37. Townsend CC, Guest E, editors. Flora of Iraq. Vols. 1-4, 8-9. Baghdad: Ministry of Agriculture and Agrarian Reform and Bentham-Moxon Trust; 1966-1985.

38. Ghalem BR, Mohamed B. Essential oil from gum of Pistacia atlantica Desf.: screening of antimicrobial activity. Afr J Pharm Pharmacol. 2009;3(3):087-091.

39. Sharifi MS. Fractionations and Analysis of Trunk Exudates from Pistacia Genus in Relation to Antimicrobial Activity. Sydney: University of Western Sydney; 2006.

40. He ML, Li A, Xu C, et al. Mechanisms of antiprostate cancer by gum mastic: NF-KB signal as target. Acta Pharmacol Sin. 2007;28(3):446-452.

41. He ML, Yuan HQ, Jiang AL, et al. Gum mastic inhibits the expression and function of the androgen receptor in prostate cancer cells. Cancer. 2006;106(12):2547-2555

42. Loutrari H, Magkouta S, Pyriochou A, et al. Mastic oil from Pistacia lentiscus var. chia inhibits growth and survival of human K562 leukemia cells and attenuates angiogenesis. Nutr Cancer. 2006;55(1):86-93.

43. Magkouta S, Stathopoulos GT, Psallidas L, et al. Protective effects of mastic oil from Pistacia lentiscus variation chia against experimental growth of Lewis lung carcinoma. Nutr Cancer. 2009;61(5):640-648.

44. Singleton V, Orthofer R, Lamuela-Raventos RA. Analysis of total phenols and other oxidation substrates and antioxidants by means of Folin-Ciocalteu reagent. Meth Enzymol. 1999;299:152-175.

45. Chouhan HS, Singh SK. Phytochemical analysis, antioxidant and antiinflammatory activities of Phyllanthus simplex. J Ethnopharmacol. 2011;137:1337-1344.

OncoTargets and Therapy

\section{Publish your work in this journal}

OncoTargets and Therapy is an international, peer-reviewed, open access journal focusing on the pathological basis of all cancers, potential targets for therapy and treatment protocols employed to improve the management of cancer patients. The journal also focuses on the impact of management programs and new therapeutic agents and protocols on
46. Ibrahim MY, Abdul AB, Ibrahim TAT, Wahab SIA, Elhassan MM, Mohan S. Attenuation of cisplatin-induced nephrotoxicity in rats using zerumbone. Afr J Biotechnol. 2012;9(28):4434-4441.

47. Zahra S, Iraj J, Farideh N. Antiangiogenic and antiapoptotic effects of green synthesized zinc oxide nanoparticles using Sargassum muticum algae extraction. Cancer Nanobiotechnol. 2018;9(3):1-16.

48. Ng KB, Bustamam A, Sukari MA, et al. Induction of selective cytotoxicity and apoptosis in human T4-lymphoblastoid cell line (CEMss) by boesenbergin a isolated from boesenbergia rotunda rhizomes involves mitochondrial pathway, activation of caspase 3 and $\mathrm{G} 2 / \mathrm{M}$ phase cell cycle arrest. BMC Complement Altern Med. 2013;13(1):41.

49. Namvar F, Azizi S, Rahman HS, et al. Green synthesis, characterization, and anticancer activity of hyaluronan/zinc oxide nanocomposite. Onco Targets Ther. 2016;9:4549-4559.

50. Rahman HS, Rasedee A, How CW, et al. Antileukemic effect of zerumbone-loaded nanostructured lipid carrier in WEHI-3B cell-induced murine leukemia model. Int J Nanomed. 2015;10:1649-1666.

51. Dai J, Mumper RJ. Plant phenolics: extraction, analysis and their antioxidant and anticancer properties. Molecules. 2010;15(10):7313-7352.

52. Rezaei PF, Fouladdel S, Hassani S, et al. Induction of apoptosis and cell cycle arrest by pericarp polyphenol-rich extract of Baneh in human colon carcinoma HT29 cells. Food Chem Toxicol. 2012;50(3):1054-1059.

53. Bozorgi M, Memariani Z, Mobli M, Salehi Surmaghi MH, ShamsArdekani MR, Rahimi R. Five Pistacia species (P. vera, P. atlantica, $P$. terebinthus, $P$. khinjuk, and $P$. lentiscus): a review of their traditional uses, phytochemistry, and pharmacology. The Scientific World Journal. 2013;2013:219815.

54. Bibi Y, Nisa S, Zia M, Waheed A, Ahmed S, Chaudhary MF. The study of anticancer and antifungal activities of Pistacia integerrima extract in vitro. Indian J Pharm Sci. 2012;74(4):375-379.

55. Lampronti I, Saab A, Gambari R. Medicinal plants from Lebanon: effects of essential oils from Pistacia palaestina on proliferation and erythroid differentiation of human leukemic K562 cells. Minerva Biotecnol. 2005;17(3):153.

56. Balan KV, Prince J, Han Z, et al. Antiproliferative activity and induction of apoptosis in human colon cancer cells treated in vitro with constituents of a product derived from Pistacia lentiscus L. var. chia. Phytomedicine. 2007;14(4):263-272.

57. Rahbar Saadat Y, Barzegari A, Zununi Vahed S, et al. Cyto/genotoxic effects of Pistacia atlantica resin, a traditional gum. DNA Cell Biol. 2016;35(6):261-266.

58. Shiraishi H, Okamoto H, Yoshimura A, Yoshida H. ER stress induced apoptosis and caspase 12 activation occurs down-stream of mitochondrial apoptosis involving Apaf1. J Cell Sci. 2006;119:3958-3966.

59. Xu C, Bailly-Maitre B, Reed JC. Endoplasmic reticulum stress: cell life and death decisions. J Clinical Investig. 2005;115:2656-2664.

60. Russo R, Corasaniti MT, Bagetta G, Morrone LA. Exploitation of cytotoxicity of some essential oils for translation in cancer therapy. e-CAM. 2015;2015:397821.

61. Namvar F, Mohamad R, Baharara J, Zafar-Balanejad S, Fargahi F, Rahman HS. Antioxidant, antiproliferative, and antiangiogenesis effects of polyphenol-rich seaweed (Sargassum muticum). BioMed Research International. 2013;2013:1-9.

patient perspectives such as quality of life, adherence and satisfaction The manuscript management system is completely online and includes a very quick and fair peer-review system, which is all easy to use. Visit http://www.dovepress.com/testimonials.php to read real quotes from published authors. 